\title{
Lusioersily
}

\section{Student Teachers' Perceptions about Inclusive Classroom Teaching in Northern Ireland Prior to Teaching Practice Experience}

Lambe, J., \& Bones, R. (2006). Student Teachers' Perceptions about Inclusive Classroom Teaching in Northern Ireland Prior to Teaching Practice Experience. European Journal of Special Needs Education, 21(2), 167-186. https://doi.org/10.1080/008856250600600828

Link to publication record in Ulster University Research Portal

Published in:

European Journal of Special Needs Education

Publication Status:

Published (in print/issue): 01/05/2006

DOI:

10.1080/008856250600600828

Document Version

Publisher's PDF, also known as Version of record

\section{General rights}

Copyright for the publications made accessible via Ulster University's Research Portal is retained by the author(s) and / or other copyright owners and it is a condition of accessing these publications that users recognise and abide by the legal requirements associated with these rights.

\section{Take down policy}

The Research Portal is Ulster University's institutional repository that provides access to Ulster's research outputs. Every effort has been made to ensure that content in the Research Portal does not infringe any person's rights, or applicable UK laws. If you discover content in the Research Portal that you believe breaches copyright or violates any law, please contact pure-support@ulster.ac.uk. 


\title{
Student teachers' perceptions about inclusive classroom teaching in Northern Ireland prior to teaching practice experience
}

\author{
Jackie Lambe* and Robert Bones \\ University of Ulster, Northern Ireland
}

\begin{abstract}
This paper seeks to obtain the views of student teachers in Northern Ireland as to the benefits and challenges of inclusive education and the key issues that may need to be addressed to ensure they become effective teachers in an inclusive classroom. Because of the system of academic selection that has prevailed in Northern Ireland, issues relating to inclusion have been difficult to resolve mainly because principles of inclusion are at odds with existing structures. By 2008, however, academic selection is to be set aside and it would seem reasonable to believe that more inclusive practices will be adopted by all schools. Positive attitudes towards inclusion by practitioners will be essential in ensuring successful implementation. The majority of students entering Initial Teacher Education (ITE) programmes in Northern Ireland have been traditionally drawn from the academic grammar school sector where classroom contact with pupils who have diverse special educational needs may have been minimal. The results of this study show that while many student teachers claim to support inclusive policies, they believe that lack of appropriate preparation, concerns about class size, resources, managing other adults and coping with increasing numbers of pupils with diverse special educational needs are the key issues to be addressed within ITE in advance of the radical changes planned. Despite claiming to support inclusion, substantial numbers did not believe the removal of academic selection was the best way to ensure equality of provision for all pupils.
\end{abstract}

Keywords: Academic selection; Attitudes; Inclusion; Initial Teacher Education (ITE); Virtual learning environment (VLE)

\section{Introduction}

While policy and legislation may enforce equality of access to educational opportunities for all, it is more problematic to ensure attitudes of acceptance and tolerance

* Corresponding author. University of Ulster School of Education, Cromore Road, Coleraine BT52 1SA, Northern Ireland. Email: je.lambe@ulster.ac.uk 
among educators. Research has shown that one of the most important predictors of successful inclusion of pupils with disabilities into mainstream classrooms is the attitude of teachers (Coates, 1989; Bacon \& Schultz, 1991; Semmel et al., 1991). Studies by Wilczenski (1991), Barton (1992), Scruggs and Mastropieri (1996), Avramidis et al. (2000) and Vaughan et al. (1996) cite the attitudes of teachers towards pupils with special educational needs as a key factor in determining the success or failure of inclusive education. As it is the teacher who will implement and ultimately make the difference to any educational change (Hargreaves, 1993), then a positive attitude towards inclusion must be considered a necessary prerequisite to the successful implementation of inclusion policies in the classroom.

Research, however, is divided on how actually to promote positive attitudes among educators towards inclusion. Some research studies assert that teachers with more experience teaching students with disabilities in their classes show more favourable attitudes toward inclusion (Leyser et al., 1994; Bender et al., 1995; LeRoy \& Simpson, 1996), while increased knowledge and experience about inclusive practices may also promote positive attitudes (Shoho et al., 1997). Conversely, however, research has also reported that trainee teachers often showed more willingness to accept pupils with SEN than more experienced teachers (Harvey, 1985; Forlin et al., 1996; Forlin, 1998). In their study on attitudes of pre-service teachers towards persons with disabilities, Alghazo et al. (2003) found generally negative attitudes and did not show that increased contact with persons with disabilities affected attitudes positively. However, those students who had first taken courses relating to educational approaches to individual difference showed more positive attitudes to inclusion than those who had not. Studies of both pre-service and in-service teacher attitudes towards inclusion of pupils with special educational needs (SEN) in mainstream classrooms have shown that attitudes were influenced by the amount of education and academic preparation they received (Wilczenski, 1991; Avramidis et al., 2000), concluding that improving and increasing training provision at the pre-service phase of teacher education would be the most effective method of promoting better attitudes to inclusion.

Positive attitudes to inclusion and confidence in the ability to teach in an inclusive classroom can be seen as a learned process that is strongly influenced by the amount and the kind of contact teachers and student teachers have with pupils with SEN. If we can accept this premise, then good appropriate preparation would be seen as key to seeking successful inclusive outcomes (Smith et al., 1986). The importance of training in helping to form positive attitudes towards inclusion has also been further supported by research. Beh-Pajooah (1992) and Shimman (1990) found that teachers who had specific training to teach students with learning difficulties expressed more positive attitudes towards inclusion compared to those who had not. Other research concurring with this (Centre \& Ward, 1987; Avramidis et al., 2000; Van Reusen et al., 2000) cited training and staff development as having a key role to play in developing positive attitudes towards inclusion. Marshall et al. (2001), in their study of student teachers' attitudes towards pupils with speech and language difficulties, also concluded that commitment towards inclusion is needed and increased 
knowledge skills and training related to supporting pupils with these specific special educational needs would increase the teachers' abilities to support pupils effectively.

Improvements in teacher education and opportunities for open discussion about concerns relating to inclusion would help to develop confidence when teaching in an inclusive classroom. There is, then, an imperative that pre-service programmes should develop ways and means of promoting positive attitudes towards the integration of pupils with diverse special educational needs into mainstream classrooms (Kauffmann \& Hallahan, 1981).

\section{Defining inclusion in the Northern Ireland context}

Armstrong et al. (2000, p. 3) argued that the successful pursuit of inclusion may require a struggle against existing cultural and ideological forces that may have legitimized practices and policies that may be seen as exclusionist. In Northern Ireland, for example, post-primary education is presently far from anything that might be regarded as inclusive and is based very firmly on a process of academic selection. At the end of what in the UK is called the key stage 2 (ages 8-11 years) phase of a child's education, pupils in Northern Ireland will sit two 1-hour written papers to test their abilities in English, mathematics and science. The results of these tests are then used to select the individual child's post-primary school. Those who score in the top 30\% are likely to find places in an academically selective school (grammar school), while the rest (approximately $70 \%$ of the pupil population) will attend non-selective schools. While a small number of pupils who have been assessed as having a special educational need may find a place in a selective school, the likelihood will be that the nature of their special need will be a physical disability that has not affected their intellectual capacity.

In effect, a place may be found in a grammar school for a child with a disability so long as the child is deemed to have the intellectual abilities required to succeed in an academically elitist setting. While the majority of pupils (including many with diverse special educational needs) will attend non-selective schools, those deemed to have moderate to severe learning difficulties will generally attend a special school. Issues relating to inclusive schooling have been problematic in Northern Ireland, since the fundamental principles of inclusion could be considered to be at odds with such a rigid selective system. The perpetuation of the existing system which selects a perceived academic elite ( $30 \%$ of learners) to a better-funded setting (funding is age related and grammar schools have a higher percentage of 16-18 pupils) suggests that inclusion is all very well for everyone else ( $70 \%$ of learners), but not for those who score well in two 1-hour written tests completed at the age of 11 .

Critics of academic selection cite social bias in favour of the middle class, the distortion of the curriculum, the stress placed on very young learners, the increase in 'coaching' and the sense of failure and stigma felt by those who fail as good reasons for its removal (Gallagher \& Smith, 2000; Carlin, 2003).

Northern Ireland is emerging from a long period of internal conflict and beside growing political stability there have also been some radical developments within 
education. A large-scale revision of the curriculum (CCEA, 2003), and various reports dealing with the issue of post-primary provision (Burns Report, 2001; Costello Report, 2004) have led to a recognition that changes are necessary to ensure that all pupils receive a more equitable educational experience. By 2008, academic selection is to be set aside, and it would seem reasonable to believe that more inclusive practices will be adopted in all schools. The Special Education and Disabilities Act 2002 (SENDA) is about to be adopted for implementation in the province, bringing it in line with the rest of the $\mathrm{UK}$, and issues surrounding inclusion are now very much to the forefront in local educational debate. The Costello Report (2004) identified inclusive education and improved provision for SEN as key issues for mainstream schools, particularly at the post-primary level.

As the curriculum in Northern Ireland is about to become much more skills based than ever before, there may also now be real opportunities if the will is there for the province to embrace a more generative and far-reaching model of inclusive schooling (Pugach, 1995). The attitudes towards inclusion and perceptions of their training needs of those entering Initial Teacher Training programmes in Northern Ireland will have important implications for the development of these programmes.

What might inclusive education actually mean within a Northern Ireland context? In a DfEE report on effective practice in inclusion (Ainscow et al., 1998), one of the key findings was confusion by many stakeholders over what inclusion actually means. Generally it was seen as moving students from special to mainstream schools. More recently, the QCA report on research to investigate curriculum, assessment and qualifications in inclusive learning found that the statement on inclusion from the National Curriculum was associated mainly with SEN provision, with 'few realizing it has far wider implications for other marginalized groups of learner' (DfES, 2004). The same report found that while the goal of the inclusion chapter was 'laudable', the 'lack of guidance and training on inclusion' made it impossible to satisfactorily fulfil the provision.

At one end of the scale, commitment to fully inclusive education could in theory lead to the dismantling of special schools, so that the majority of resources and support would be directed at the mainstream. Certainly there is a clear message contained within SENDA that mainstream education is to be seen as the preferred option for the majority of pupils. Those who support fully inclusive schooling, as opposed to integrationists, take the view that there is a present tendency within education to focus on the 'normalization' of the individual (Vlachou, 2004) within existing systems, therefore avoiding the challenge of re-evaluating the systems themselves. Armstrong et al. (2000, p. 62) defined inclusion as: 'arrangements which increase participation or contact between a disabled pupil or pupils in some form of segregated setting and those in mainstream education settings.' Is inclusion, then, simply to integrate SEN pupils using new methods, or to 'recast education from the ground up?' (Pugach, 1995, p. 216). The former Pugach calls the additive model of inclusion, as it encourages change from within the already confirmed SEN practice. This would be recognizable within present school environments where modification and adaptation of the existing curriculum would be routinely used to accommodate 
difference. In contrast, the generative model of inclusion may be a means of transforming thinking on the whole concept. Existing school systems and curricula would necessitate redesign in a much more complex and extensive way. Inclusion would be seen as part of a total rethink as to what it means to educate all children in parallel with coordinated curriculum and social reform (Pugach, 1995).

\section{Initial teacher education in Northern Ireland}

In addressing the challenge of inclusion there has been recognition of the need to take account of the quality and appropriateness of the present provision within Initial Teacher Education (ITE). Most of those wishing to teach in a post-primary school will complete a one-year subject-based Postgraduate Certificate in Education (PGCE), offered at one of the relevant higher education institutions in Northern Ireland. The majority of students entering ITE programmes are products of the present highly selective system and are largely (though not exclusively) drawn from the more academic grammar school sector. For example, at the University of Ulster, which trains almost one-half of student teachers studying for a PGCE in the province, $72.4 \%$ of the intake in 2005 had attended an academically selective school, while $27.6 \%$ experienced non-selective schooling. In the Northern Ireland school system these figures are almost completely reversed, with $70 \%$ of post-primary pupils attending a school that is non-selective.

Since most experienced teachers and those in ITE programmes in Northern Ireland are likely to have been educated in classrooms where they would have had little exposure to other young people with even very mild learning difficulties, this may have a significant influence on their attitudes towards teaching in an inclusive classroom. While no assumption can be made that such potential influence will equate to negative attitudes, it is still a variable worth considering. Since inclusion is considered the keystone of today's government education policy (see Booth et al., 2000 , p. 15), then for those now embarking on a teaching career there is a clear expectation that for the first time, 'Every teacher should expect to teach children with SEN' (DfES, 2004, p. 56), so promotion of positive attitudes towards inclusion and SEN are vital.

Although the Department for Education (Northern Ireland) has yet to reveal exactly what the new model for post-primary schooling is to be after 2008, the removal of academic selection offers a strong indication that it will be much more inclusive than ever before. There is, of course, always the possibility that the province could embrace a generative model and rebuild the system from the ground up. This would require radical reform of educational structures so as to be able to meet the needs of all pupils (Mittler, 1995) and the move towards inclusive education would be seen within the context of educational reconceptualization (Slee, 2000). Alternatively, the system may lean more towards integration than full inclusion, and categories of special educational need will still determine the extent of inclusion. Research has shown, however, that many teachers are wary of aspects of inclusive practice, expressing concern about their status and reputation as successful teachers, the 
perception of extra workload and responsibility, as well as the additional help and facilities required (Vaughan et al., 1996). Scruggs and Mastropieri (1996) found that teachers were highly suspicious of changing practice and the lack of communication and time for training to support students offered.

Whatever system is adopted, those who are responsible for ITE have a duty to provide the kind of professional and educational experience necessary to support good classroom practice. Villa et al. (1996) found that teacher support for inclusion had often increased by the end of the implementation process when confidence improved alongside expertise. Guskey (1986) stated that increased mastery through guidance and support in trying out new procedures and showing positive outcomes could also promote positive attitudes. Equally, teachers can claim positive attitudes towards the ideal of inclusion but may still feel they lack the necessary knowledge and skills to teach effectively in an inclusive setting. In their study of student teachers' attitudes to inclusion in Northern Ireland, Lambe and Bones (in press) found that early in the Initial Teacher Education (ITE) phase of training many student teachers had not yet formed clear opinions about teaching in an inclusive setting and cited this as 'the most opportune moment to cultivate positive attitudes through exposure to a carefully designed academic learning programme about inclusion'. Those about to enter the profession in Northern Ireland need to be prepared in such ways as they can positively and confidently embrace more inclusive practices within a system that will inevitably be very different to their own educational experience.

Wishing to respond to the urgent need to prepare student teachers for a radically changing educational landscape and being cognizant of research findings that support the importance of improving attitudes through educational study, a programme was designed by the School of Education at the University of Ulster with the aim of supporting and promoting positive attitudes towards inclusion among PGCE students.

\section{Using a virtual learning environment to support discussion and reflection on issues relating to inclusion}

In Northern Ireland the Postgraduate Diploma in Education (PGCE) year is 36 weeks in length and is a marriage of theory and practice with 24 weeks spent gaining school-based experience supported by 12 weeks based in a higher education institution (HEI). It is a short, intensive programme and demands of the curriculum make time a precious commodity. All student teachers take part in a generic programme of face-to-face lectures, seminars and workshops designed to help inform and prepare them for the practicalities of teaching an increasingly diverse group of pupils found in mainstream post-primary schools. These sessions are further supported by subjectspecific inputs. The University of Ulster supports eight post-primary PGCE programmes: Art and Design, English, Geography, History, Home Economics, Music, Physical Education and Technology and Design. Because of subject-specific accommodation requirements, the Physical Education and Technology and Design programmes are taught on a site that is 50 miles away from where the other six 
subjects are based. In an attempt to be more proactive and promote what might be a more aggressive approach, an extended enrichment programme dealing specifically with issues of inclusion and SEN was piloted as an elective. Providing a blended online option for the Inclusion and SEN elective ensured equality of opportunity and provision for the student teachers on all the PGCE programmes including the two subjects who were not on the main campus.

The elective programme used Blackboard, a virtual learning environment (VLE) to support student learning. Use of a VLE was already familiar to the students who use it for various activities within their individual subject areas and as a support and communication mechanism when on teaching practice. Forty-one students from a total student group of 125 chose Inclusion and SEN as their elective programme (the choices offered were from a range of areas, including Local and Global Citizenship, Personal Health and Social Education, Religious Education, and Drama and Media Education). The programme was developed to last for the 12 weeks the students spent in the university setting and was divided into two six-week blocks leading towards each of two nine-week school-based placements. Overall, three hours a week were set aside for each elective, and while the others were taught face to face, the Inclusion and SEN programme was designed and taught for the most part within an online environment.

Participating students were provided with an online study guide, available to them within the Course Materials area of the VLE. This would be the student's main reference to content, structure and activities associated with the online course. The elective also used a resource-based website, specifically designed by the School of Education at the University of Ulster, to support learning on Inclusion and SEN in ITE (this is an open site and can be viewed at: http://www.socsci.ulster.ac.uk/education/scte/sen/index.html).

The programme offered students a range of opportunities to facilitate learning, including jigsaw learning activities to support extended reading, collaborative activities such as group presentations on their study of types of learning disabilities, teaching strategies based on case studies, differentiated learning and classroom management issues. The programme also allowed the students to pose questions to a range of 'experts online'. These were professionals working to support pupils with SEN and included a special educational needs coordinator (SENCO), a young teacher who had just completed induction, an educational psychologist and an academic researching in the area of human rights and inclusion. Discussion (both synchronous and asynchronous), based on their reading and comprehension of key texts, was used to encourage the students to articulate their thinking through professional dialogue and was an important scaffold on which the online programme was built. Because of the online nature of the elective, the teaching philosophy had a strong constructivist base and incorporated structured discussion, groupwork and an emphasis on 'interpreting concepts in the light of one's own experience' (Weller, 2002, p. 65).

The course was centred on the set of student tasks, projects and assignments that constitute the learning the students would engage in. These tasks had a level of 
authenticity aimed at sustaining interest and activity on the part of the online student. There were many benefits of using the online environment. Because of the time restraints on the elective programme, online discussion allowed participants to access the site at any time and discussions were not time restricted as they might be in a traditional classroom setting. This allowed more long-term engagement with the topic or theme that could be revisited as the programme progressed. Much has been written about the potential advantage that email and conferencing can bring to teaching and learning and, in particular, the capacity of computer conferencing to provide a forum for shared reflection on professional practice.

Lambe and Clarke (2003) concluded that conferencing offered opportunities to foster 'high-quality professional dialogue' when used early to support student teachers in Initial Teacher Education programmes, while Laurillard (1996) asserted that these online communication mechanisms can provide the discursive elements necessary to the success of academic learning; furthermore, text-based communications can promote 'thoughtful and reflective commentary' because the act of writing requires greater reflection than speaking. Since the key aim of the elective was to encourage positive attitudes to inclusion, the online discussions placed less emphasis on the tutor and much more on the learner communicating with his or her peers on the themes set by the programme. For research purposes the extensive use of online discussions provided a rich source of qualitative data on the broader issues of how the students perceived inclusion as a model for education in Northern Ireland and the challenges it offered them as new teachers about to enter the profession.

\section{Research questions}

This study set out to explore the following questions:

1. What do student teachers perceive are the main benefits and challenges for inclusive education in Northern Ireland post-2008?

2. What key issues do student teachers feel need to be addressed to ensure they can become effective teachers in an inclusive classroom?

\section{Method}

\section{Participants}

The study was qualitative. A sample group of 41 was drawn from the full 2004/05 cohort of 125 post-primary PGCE students attending the University of Ulster. The sample group who had opted to take the elective Inclusion and SEN programme had given reasons within an earlier survey for this choice. These reasons divided into three categories: those who felt they had no experience of SEN (68\%), those who feared not being able to cope in an inclusive setting $(13 \%)$ and those who had some experience working with special educational needs, or those who felt they had a special need while at school that was not well catered for $(9 \%)$. The other elective programmes where strongly subject influenced, for example, the majority of History and Geography 
students chose Local and Global Citizenship as their elective. However, from the total student group of 125, Inclusion and SEN was the first or second preferred choice of 93 students (74\%), who cited the same or similar three reasons for this choice. Because of its popularity with the student body and on completion and evaluation of this pilot, it is likely to become a compulsory element of the overall programme. It also gives credence to the claim that as a sample this group is representative of the views of the larger student body.

\section{Instrument}

Early in the PGCE year and prior to the students' first teaching practice experience, a survey had been administered with the aim of gathering information regarding student teachers' attitudes towards inclusion and inclusive practices. This survey contained 27 statements relating to general inclusion issues alongside statements about inclusion and SEN with specific relevance to the Northern Ireland context; it had been validated in a previous study (Lambe \& Bones, in press) and was found to be reliable (for the questions see Appendix 1). It had sought to ascertain student teachers' attitudes to Northern Ireland's academically selective system and their perceptions as to how its removal would affect the successful promotion of inclusive education. The main findings from the survey were then used to inform the design of the elective programme. Analysis of the survey results also led to the formulation of research questions for this qualitative study. The survey had been administered at the start of the PGCE year, before the students had discussed issues surrounding inclusion or SEN, or had been introduced to academic theory on the subject. The aim was to gain insight into student attitudes at a point prior to the many external influences the PGCE programme would bring to them. Results elicited a number of themes including:

- beliefs about the purpose of schooling;

- attitudes about organizational issues within teaching;

- concerns or anxieties about teaching within an inclusive educational setting;

- personal beliefs and attitudes towards the ideology of inclusive education.

The responses from the survey were analysed using Formic Data Capture software, and cross-tabulations enabled results to be classified in total and thematically. From the total student group $(n=125)$ who took part in the quantitative aspect of the research, 41 participants formed the sample group and their words are used to provide qualitative data for this study. These students took part in a series of asynchronous and synchronous discussions on a range of topics relating to their experiences, beliefs and attitudes towards inclusion. The purpose of these online discussions was to enable the participants to openly articulate their thoughts and enable 'thick description' (see Geertz, 1973). They were designed to enrich and validate the data collected from the survey and allowed the researchers to qualitatively explore and clarify the emerging themes. The sample was grouped at random for the discussions with seven discussion groups of five and one group of six members. 
Discussions were enriched by reading activities aimed at promoting reflection on a range of issues relating to inclusion. Meaningful discourse requires a process of collaboration and social negotiation where the goal is to share different viewpoints and collaborate on a problem-solving and knowledge-building activity (see Duffy \& Cunningham, 1991).

Online communication facilities are now increasingly used to encourage articulation, reflection and negotiation. To provide for meaningful discourse and yet ensure the discussions were as free-ranging as possible, only limited structuring or protocols were imposed. Each group nominated a facilitator from within their group, whose role it was to be timekeeper (the discussions were time limited to 45 minutes) and to remind the group of the focus of the discussions.

Using the VLE allowed the discussions to be archived and the transcripts constitute data for analysis. The data were analysed thematically, initially using the themes identified by the earlier survey. The analysis followed a qualitative approach (Vaughan et al., 1996), and the researchers specifically searched for the following information:

- Key themes or common threads found by both researchers reading and rereading the archived discussion.

- Specific phrases or sentences that were used regularly by the students within the discussions so as to aid the selection of category headings relevant to the research.

This was followed up by the two researchers (authors of this paper) who were able to create a short coding system based on their understanding of whether the students were (1) relating new knowledge to prior knowledge, (2) interpreting content through the analysis, synthesis and evaluation of others' understanding and (3) making inferences. The discussions transcripts were also downloaded by the sample group themselves, who used the same process to analyse their own group discussion. This formed part of the inter-rater checks and undertaken as part of the analysis process to ensure reliability and validity of themes. The students' own words expressed within the discussions were also used to illustrate each category heading and add support to the findings.

The data were gathered from two online discussions conducted with the sample group and findings from these provide the results for this study.

\section{Results and discussion}

The results of the survey had indicated some contradictions in student attitudes towards inclusion - for example, while $82.2 \%$ agreed that all teachers should experience teaching pupils with special educational needs, $44.9 \%$ stated they would personally prefer to teach in a selective educational system if given the choice. There were also a considerable number who did not feel ready either to agree or disagree with some of the statements. This was not totally unexpected as the survey was carried out prior to any theoretical discussion or concentrated teaching and before the students had experienced classroom practice. The survey, however, did offer some insight into 
student attitudes to inclusion at a point when they might be as yet uninfluenced by academic theory or classroom practice. The aim of the online discussions, conducted as part of the elective, was to provide a platform to encourage group discussion and the sharing of ideas and experiences so as to extrapolate opinions and perceptions more fully than the early survey had allowed.

Themes emerging from research question 1: 'What do student teachers perceive are the main benefits and challenges for inclusive education in Northern Ireland post-2008?'

The first online discussion asked the group to reflect on their personal views on inclusion as a model for Northern Ireland schools of the future. To provide an enriched learning environment the students first viewed a presentation based on 'Excellence for all Children meeting special educational needs' (DfEE, 1997a), on the developments in special needs and inclusion legislation and policy since the 1944 Education Act (see DfEE, 1997). At the start of the discussion, they had also been given a working definition of inclusion that stated inclusion should be taken to mean 'mainstream schools accommodating a full diversity of pupils'. In the analysis of the discussion archives all participants claimed support for the philosophy of inclusion and appeared to strongly favour it as a future model for Northern Ireland. The student discussion related to the kind of challenges as well as the positive benefits they felt inclusion would bring to education in Northern Ireland. Table 1 outlines the main perceived benefits and challenges the students articulated in the discussion. Quotations taken directly from the student discussions are used to illustrate each of the benefits and challenges named.

Table 1. Main issues relating to student attitudes to inclusion

\begin{tabular}{lccc}
\hline Statements & $\begin{array}{c}\text { Agree } \\
(\%)\end{array}$ & $\begin{array}{c}\text { Don't know } \\
(\%)\end{array}$ & $\begin{array}{c}\text { Disagree } \\
(\%)\end{array}$ \\
\hline $\begin{array}{l}\text { 1. I think all teachers should experience teaching } \\
\text { pupils with special educational needs }\end{array}$ & 82.2 & 12.1 & 5.6 \\
$\begin{array}{l}\text { 2. I think that streaming is the best practice for } \\
\text { dealing effectively with pupils of different abilities }\end{array}$ & 48.1 & 37.5 & 39.3 \\
$\begin{array}{l}\text { 3. I think that changing education system in } \\
\text { Northern Ireland from selective to a non-selective } \\
\text { one is the best way to cater for all pupils }\end{array}$ & 15.9 & & \\
$\begin{array}{l}\text { 4. I am concerned I will not have the skills required } \\
\text { to teach special educational needs in an inclusive } \\
\text { setting }\end{array}$ & 57.4 & 20.4 \\
$\begin{array}{l}\text { 5. I think you need to be a special kind of teacher } \\
\text { to teach pupils with special educational needs } \\
\text { 6. I think you need a special interest in special } \\
\text { educational needs to be an effective teacher of SEN }\end{array}$ & 50.9 & 23.1 & 25.9 \\
$\begin{array}{l}\text { 7. I would prefer to teach in a selective educational } \\
\text { system if I had the choice }\end{array}$ & 44.9 & 23.9 \\
\hline
\end{tabular}




\section{Benefits}

Upholding human rights and equality: 'Inclusion in our highly selective system excludes not only children with special needs, but also children who have not attained the proper grade for grammar school. To be excluded has a deep effect on children whose grade may not be a true reflection of ability. So to the powers that be, I say, your present system fails our able children by labelling them at so young an age. Inclusion must mean the demise of selection at 11 years, an inclusive education where all children are offered choices that will reflect their abilities.'

'It is not the culture of inclusive thinking that has to be challenged but the culture of exclusive thinking.'

Social integration: 'All children can interact on the same level in the playground and learn together through structured play (primary school), sports (depending on the type of SEN) and anywhere that academic ability is less of an issue. It benefits a child with SEN mixing with other children in a mainstream school, in that it may help the child socially to gain a similar education as the rest of his/her peers.'

Building self-esteem: 'To deny a child the right to basic mainstream education is to label that child a failure from the beginning of its school career.'

Promoting better understanding: 'I feel that it is important for mainstream children to be around children with special educational needs on a daily basis as then they learn that there are people with different needs to themselves. Hopefully, this would ensure that children without special educational needs would be more understanding of their SEN schoolmates.'

'It is good for children with SEN to mix with other children as they will have to in the big, bad world. It is also important that other children in the class learn to help others with SEN as this will also help them deal with issues in the real world.'

\section{Challenges}

Impossible to teach too many diverse needs in one classroom: 'Another important issue that needs to be addressed is the willingness and cooperation from teachers. Will they want to teach a mix of abilities where the behavioural difficulties of some children will affect other pupils' learning?'

'I can't imagine how I would cope if there were too many different conditions to deal with.'

Attitudes of teachers and pupils: 'My experience of SEN was when visiting a primary school and it left me feeling worried about one child, as I noticed comments being made to a young pupil with SEN in the mainstream classroom. The other pupils complained to me that she was too slow and made their desk the last to finish in groupwork. This was in a primary 2 class, and this pupil was not regarded as a serious SEN case. I think children can be very cruel to one another and will often pick up on differences between themselves.'

'It depends what you mean by inclusion really ... I mean, surely, it's not possible or even sensible to place all pupils in mainstream schools. There are pupils who might 
benefit from this but equally I can imagine others who wouldn't ... they would be lost in some of those large schools. I think many children with special needs would definitely be much happier in the special school.'

'I believe in inclusion but it's an ideal, isn't it, really? I don't know how well it could work in reality. How can any teacher cope with all abilities and also pupils with all sorts of medical or behavioural problems and do a good job for everyone?'

Inadequate teacher education: 'There would need to be an overhaul of educational provision if we went for inclusion. Support not only for the pupil and the rest of the class, but for the teacher also. I, as a teacher, would fear that I was not qualified enough to teach in such a school. I would fear about failing the pupil as well as the rest of my class.'

Resources and class size: 'Inclusion can only work in an ideal world where government will inject more money into education, enabling smaller class numbers, more classroom assistants, and SEN-specific training for all teachers across the board. At present our system makes it impractical.'

While the sample group seemed to favour inclusion, there appeared little support for establishing the more radical model that would provide for the inclusion of all children at all times in a classroom, irrespective of their special educational need. In the discussions words such as 'utopian', 'impractical' or even 'unworkable' were used to describe this model. There was much more support for an integrative model where pupils would mix socially and in practical subject areas such as art and design and physical education. Student teachers saw providing withdrawal classes and behavioural units as the most acceptable way of supporting pupils with special educational needs in a mainstream setting, and none of the students saw this as a serious contradiction to their expressed belief in inclusion.

Themes emerging from research question 2: 'What key issues do student teachers feel need to be addressed to ensure they can become effective teachers in an inclusive classroom?'

In addressing this question the student group were challenged to engage in collaborative group discussion using the synchronous facility available through the VLE. The group were divided into six subgroups of four or five members and they worked collaboratively to agree on the main issues they felt would affect their ability to teach effectively in an inclusive classroom.

Analysis of the discussion archives shows six common areas of concern and these are shown in Table 2. Quotations taken directly from the student discussions are used to illustrate student thinking on each of these issues.

Student perceptions of key issues that should be addressed to ensure effective teaching in the inclusive classroom

Quotations are taken from the student discussions (see Table 3):

1. Inclusion should be a whole-school issue: 'All teachers' roles will need to be redefined, this will include general subject teachers, not just teachers of SEN' 
Table 2. Student teachers' perceptions of the benefits and challenges of inclusive education

\begin{tabular}{|c|c|}
\hline Benefits & Challenges \\
\hline $\begin{array}{l}\text { The philosophy of inclusion is strongly } \\
\text { linked to upholding human rights, and } \\
\text { equality }\end{array}$ & $\begin{array}{l}\text { Teaching very diverse special educational needs in an } \\
\text { inclusive setting effectively may be impossible }\end{array}$ \\
\hline $\begin{array}{l}\text { Inclusion provides an environment to } \\
\text { promote social integration }\end{array}$ & $\begin{array}{l}\text { Teacher attention may be concentrated on those who } \\
\text { demand or require most help and this may be } \\
\text { detrimental to the majority in an inclusive classroom }\end{array}$ \\
\hline $\begin{array}{l}\text { Inclusive practices offer effective means } \\
\text { to build pupil self-esteem }\end{array}$ & $\begin{array}{l}\text { Teacher and pupil acceptance of pupils with special } \\
\text { educational needs cannot be automatically assumed. } \\
\text { Attitudes may be difficult to change }\end{array}$ \\
\hline $\begin{array}{l}\text { Inclusion offers opportunities to promote } \\
\text { better understanding of diverse special } \\
\text { educational needs by all teachers and } \\
\text { pupils. Eventually this would extend to } \\
\text { the wider community }\end{array}$ & $\begin{array}{l}\text { Existing teacher education in Northern Ireland may } \\
\text { not adequately provide the knowledge and classroom } \\
\text { management skills necessary to teach effectively } \\
\text { within an inclusive classroom }\end{array}$ \\
\hline $\begin{array}{l}\text { Inclusion ensures that siblings can attend } \\
\text { the same school }\end{array}$ & $\begin{array}{l}\text { Class size and lack of resources may be major } \\
\text { challenges to the successful implementation of } \\
\text { inclusion }\end{array}$ \\
\hline
\end{tabular}

'Teachers will need to share responsibilities so as they work as a team to implement SEN in mainstream schools'

2. Training: 'Teachers will needs lots of extra training to deal with SEN pupils in mainstream'

'Training for teachers needs to be ongoing. We need good preparation for the classroom and even experienced teachers need to refresh their skills and knowledge regularly'

3. Co-teaching: 'Joint teaching and planning required from special and general education teachers, in the one class. This method will also encourage support learning, so that each teacher will learn from the other various practices and techniques that can be used to deal with the variety of learners in the classroom'

Table 3. Key issues student teachers feel need to be addressed to ensure they can become effective teachers in the inclusive classroom

1. Inclusion should be seen as a whole-school issue, not just the responsibility of the special educational needs coordinator (SENCO)

2. A need to redefine the training needs of teachers and those in ITE. There is at present no requirement for teachers to have specific qualifications to work with pupils with SEN in mainstream or in special schools

3. Co-teaching: a need to develop a strategic approach to team teaching

4. Role of the classroom assistant and training for teachers in managing support staff in the classroom

5. Providing sufficient resources and reducing class size

6. Providing training to promote positive attitudes to inclusion and SEN among all teachers 
'Teachers would need to be paired very carefully if co-teaching is to work, again training will be required if teachers are to learn to work together in harmony and so that they don't feel their space is being invaded. We think that it could work and would help the teachers to plan a better educational programme for the pupils. The work and pressure would be shared. They could co-teach but one-to-one individual attention will still be needed'

4. Classroom assistants: 'Properly train classroom assistants and the classroom teachers so they can make better use of the classroom assistant'

'Teachers need training in managing classroom assistants and other support staff'

5. Resources and class size: 'Class sizes need to be reduced and kept consistent across the system'

'Class sizes would need to be smaller to allow the teacher to focus more attention on pupils requiring assistance'

6. Attitude training: 'Teachers' attitudes need to change, so that they embrace a more shared approach toward planning and teaching'

'Peer support learning should be encouraged in the inclusive classroom, with an emphasis placed on respect for each pupil's individual differences'

'An attitude of toleration needs to be replaced for an attitude of acceptance and support'

\section{Conclusion}

Forlin et al. (1996) asserted that less experienced teachers such as those in pre-service who may only have had minimal contact with pupils with diverse special educational needs are often more positive and optimistic about the inclusion than many more experienced teachers. This assertion has, in many ways, been confirmed by this study as throughout the student discussions there was a sense that the group held generally positive attitudes to inclusion in spite of having a clear sense of the difficulties and challenges its implementation may hold, particularly within the context of Northern Ireland. The survey of the whole group indicated support for the ideal of inclusion, but some inconsistencies were indicated - when students were asked to choose a preference, many opted to retain more traditional and familiar systems. The conclusions drawn from the discussions tend to affirm the tension within the individual educator that Ainscow (2000) described as the balance that schools make between development and maintenance.

The wish to move practice forward is constantly tempered by regard for current, recognized practice and concern for the difficulties associated with implementing what might appear risk-taking change. There were also a number of student teachers who had not as yet formed strong opinions about inclusion and felt unqualified to offer informed comment, so that overall conclusions at this stage of the research need to be cautionary.

The sample group claimed a strong belief in the philosophy of inclusion but they were by no means evangelical in their belief. Throughout the discussions they were constantly modifying and re-defining inclusion to provide a structure they saw as 
workable. The final model they opted for was a version of inclusion that was more about integration and adaptation than a generative and radical overhaul of present systems, as described by Pugach (1995). A range of common threads were seen to run through the student perceptions of the conditions necessary to ensure they were effectively prepared for a future of more inclusive schooling in Northern Ireland. Reduction in class size and quality training for teachers were seen as the key issues in the effective implementation of inclusion. The research considered student perceptions of teaching in a far more inclusive educational setting than they themselves had experienced when at school.

The survey was conducted at a very early point within the ITE programme and prior to the students' first practical teaching experience. The additional period of time provided by the elective was designed to encourage deeper reflection and better understanding of the issues surrounding the successful implementation of inclusion, and there is evidence of some very positive attitudes towards many aspects of inclusive practice. The opinions expressed and attitudes reflected at this stage, however, may change dramatically in light of an extended period teaching in the classroom and the contact with an experienced teacher who may or may not be positive about inclusion.

In their review of literature on teacher attitudes towards integration/inclusion Avramidis and Norwich (2002) concluded that teachers are generally positive towards inclusion, but this is not to assume that they share a 'total inclusion approach' (p. 142) to provision for SEN. Furthermore, they add that the provision of real opportunities for training at pre-service level should be a 'top priority' (p. 142) for those who make policy. The present research would concur with this recommendation. We believe that this research has importance because while there have been international studies about the attitudes of student teachers to inclusion we have been unable to find similar studies within the context of Northern Ireland. Because of the long attachment to academic selection as the model for education in the province, adopting inclusion in practice will be a radical change for all schools and their teaching staff. To ensure successful implementation it is imperative that training provision for those about to enter the profession is designed so as to promote positive attitudes. This may require a radical rethink of current practice to ensure student teachers have the skills and attributes to teach effectively in an inclusive setting. Pugach (1995) summarized the dangers of launching inclusive classrooms without first engaging in dialogue with prospective or practising teachers or those who prepare them as: 'making the transition to new frameworks much more difficult to achieve' (p. 221).

This research is longitudinal in nature and has set out to discover the influences or events that might affect attitude change towards inclusion throughout the pre-service year and beyond into induction. The next stage will be to survey and interview the student group when they have completed their first placement in a non-selective school. They will be asked to reflect on the extent to which increased knowledge and experience based on classroom practice has affected their initial perceptions of teaching in an inclusive classroom. 


\section{References}

Ainscow, M. (2000) Reaching out to all learners: some lessons from international experience, School Effectiveness and School Improvement, 11(1), 11-19.

Ainscow, M., Farrell, P. \& Tweddle, D. A. (1998) Effective practice in inclusion and in special and mainstream schools working together (London, DfEE).

Alghazo, E. M., Hamzah, D. \& Algaryouti, I. A. (2003) Attitudes of pre-service teachers toward persons with disabilities: predictions for the success of inclusion, College Student fournal. Available online at: http://www.findarticles.com/p/articles/mi_m OFCR/is_4_37/ ai_112720415 (first accessed December 2003).

Armstrong, F., Armstrong, D. \& Barton, L. (2000) Introduction: What is this book about? in: F. Armstrong, D. Armstrong \& L. Barton (Eds) Inclusive education: policy, contexts and comparative perspectives (London, Fulton).

Avramidis, E. \& Norwich, B. (2002) Teachers' attitudes towards integration/inclusion: a review of the literature, European Fournal of Special Needs Education, 17(2), 129-147.

Avramidis, E., Bayliss, P. \& Burden, R. (2000) A survey into mainstream teachers' attitudes towards the inclusion of children with special educational needs in the ordinary school in one local education authority, Educational Psychology, 20(2), 191-211.

Bacon, E. H. \& Schultz, J. B. (1991) A survey of mainstreaming practices, Teacher Education and Special Education, 14(2), 144-149.

Barton, M. L. (1992) Teachers' opinions on the implementation and effects of mainstreaming: Chicago public schools (ERIC Document Reproduction Service No. 350802).

Beh-Pajooah, A. (1992) The effect of social contact on college teacher's attitudes towards students with severe mental handicap and their educational integration, European fournal of Special Needs Education, 7, 231-236.

Bender, W. N., Vail, C. O. \& Scott, K. (1995) Teachers' attitudes to increased mainstreaming: implementing effective instruction for students with learning disabilities, fournal of Learning Disabilities, 28, 87-94.

Booth, T., Ainscow, M., Black-Hawkins, K., Vaughn, M. \& Shaw, L. (2000) Index for inclusion: developing learning and participation in schools (Bristol, Centre for Studies in Inclusive Education).

Burns Report. Department for Education (NI) (2001) Education for the 21st century. Report by the Post-primary Review Body (Bangor, Department for Education (NI)).

Carlin, J. (2003) The Northern Ireland selective system: a wind of change, Irish fournal of Education, 24, 70-79.

Center, Y. \& Ward, J. (1987) Teachers' attitudes towards the integration of disabled children into regular schools, Exceptional Child, 34, 41-56.

Coates, R. D. (1989) The Regular Education Initiative and opinions of regular classroom teachers, Fournal of Learning Disabilities, 22, 532-536.

Costello Report. Department for Education (NI) (2004) Future post-primary arrangements in Northern Ireland. Advice from the Post-primary Working Group (Bangor, Department for Education (NI)).

Council for the Curriculum, Examination and Assessment (2003) Pathways-proposals for curriculum and assessment at keystage 3. Available online at: http://www.ccea.org.uk/KS3/ (Accessed June 2005).

Department for Education and Employment (1997) Excellence for all children: meeting special educational needs (London, HMSO).

Department of Education and Skills (2004) Removing barriers to achievement. The government strategy for SEN (London, DfES).

Duffy, T. M. \& Cunningham, D. J. (1996) Constructivism: implication for the design and delivery of instruction, in: D. H. Johanassen (Ed.) Handbook of research for educational communications and technology (New York, Simon \& Schuster Macmillan), 170-198.

Forlin, C. (1996) Educators' beliefs about inclusive practices in Western Australia, British fournal of Special Education, 22, 179-185 
Forlin, C. (1998) Inside four walls, Australian fournal of Special Education, 22(2), 96-106.

Forlin, C., Hattie, J. \& Douglas, G. (1996) Inclusion: is it stressful for teachers? fournal of Intellectual and Developmental Disability, 21, 199-217.

Gallagher, T. \& Smith, A. (2000) The effects of the selective system of secondary education in Northern Ireland, Vols 1 and 2 (Bangor, Department for Education (NI)).

Geetz, C. (1973) The interpretation of cultures (New York, Basic Books).

Great Britain. Statutes (1944) Education Act (London, HMSO).

Great Britain. Statutes (2002) Special Educational Needs and Disabilities Act (SENDA) (London, HMSO).

Guskey, T. R. (1986) Staff development and the process of teacher change, Educational Researcher, $15,5-12$.

Hargreaves, A. (1993) Individualism and individuality: reinterpreting teacher culture, in: J. W. Little \& M. McLaughlin (Eds) Teachers' work: individuals, colleagues and contests (New York, Teachers College Press).

Harvey, D. H. (1985) Mainstreaming: teachers' attitudes when they have no choice in the matter, Exceptional Child, 32, 163-173.

Kauffmann, J. M. \& Hallahan, D. P. (Eds) (1981) Handbook of special education (Englewood Cliffs, NJ, Prentice-Hall).

Lambe, J. \& Bones, R. (in press) Student teachers' attitudes to inclusion: implications for initial teacher education in Northern Ireland, International fournal of Inclusive Education.

Lambe, J. \& Clarke, L. (2003) Initial teacher education online: factors influencing the nature of interaction in computer conferencing, European fournal of Teacher Education, 26(3), 351-363.

Laurillard, D. (1996) The changing university. Available online at: http://it.coe.uga.edu/itforum/ paper13/paper13.html (accessed June 2005).

LeRoy, B. \& Simpson, C. (1996) Improving student outcomes through inclusive education, Support for Learning, 11, 32-36.

Leyser, Y., Kapperman, G. \& Keller, R. (1994) Teacher attitudes toward mainstreaming: a crosscultural study in six nations, European Fournal of Special Needs Education, 18, 44-54.

Marshall, J., Ralph, S. \& Palmer, S. (2001) 'I wasn't trained to work with them': mainstream teachers' attitudes to children with speech and language difficulties, International fournal of Inclusive Education, 6, 199-215.

Mittler, P. (1995) Education for all or for some? International principles and practice, Australasian Fournal of Special Education, 19(2), 5-15.

Pugach, C. M. (1995) On the failure of imagination in inclusive schooling, fournal of Special Education, 29, 212-223.

Scruggs, T. E. \& Mastropieri, M. A. (1996) Teacher perceptions of mainstreaming inclusion, 1958-1995: a research synthesis, Exceptional Children, 58, 37-42.

Semmel, M. I., Abernathy, T. V., Butera, G. \& Lesar, S. (1991) Teacher perceptions of the Regular Education Initiative, Exceptional Children, 58, 9-24.

Shimman, P. (1990) The impact of special needs students at a further education college: a report on a questionnaire, Fournal of Further and Higher Education, 14, 83-91.

Shoho, A. R., Katims, D. S. \& Wilks, D. (1997) Perceptions of alienation among students with learning disabilities in inclusive and resource settings, High School fournal, 81(9), 28-36.

Slee, R. (2000) Social justice and the changing directions in educational research: the case of inclusive education, International fournal of Inclusive Education, 5, 167-178.

Smith. T. E., Price, B. J. \& Marsh, G. E. (1986) Mildly handicapped children and adults (St Paul, MN, West).

Van Reusen, A. K., Shoho, A. R. \& Barker, K. S. (2000) High school teacher attitudes toward inclusion, High School fournal, 84, 7-20.

Vaughan, S., Schumm, J. S. \& Sinagub, J. (1996) Focus group interviews in education and psychology (Thousand Oaks, CA, Sage). 
Villa, R. A., Thousand, R. A., Meyers, H. \& Nevis, A. (1996) Teacher and administrator perceptions of heterogeneous education, Exceptional Children, 6, 34-39.

Vlachou, A. (2004) Education and inclusive policy-making: implications for research and practice, International fournal of Inclusive Education, 8, 3-21.

Weller, M. (2002) Delivering learning on the net: the why, what and how of online education (London, Kogan Page).

Wilczenski, F. L. (1993) Changes in attitudes toward mainstreaming among undergraduate education students. Educational Research Quarterly, 17, 5-17.

\section{Appendix 1. Survey questions}

1. I think all teachers should experience teaching pupils with special educational needs.

2. I think you need to be a special kind of teacher to teach pupils with special educational needs.

3. I think you need a special interest in special educational needs to be an effective teacher of SEN.

4. I have no experience in working with special educational needs.

5. I am concerned I will not have the skills required to teach special educational needs in an inclusive setting.

6. I think that streaming is the best practice for dealing effectively with pupils of different abilities.

7. I think that changing the education system in Northern Ireland from a selective to a non-selective one is the only way to cater for all pupils.

8. Having pupils with diverse special educational needs in the classroom is unfair to other pupils who may be held back.

9. A teacher should be concerned with educational issues and not be expected to deal with pupils' emotional and behavioural problems.

10. I would prefer to teach in a selective educational system if I had the choice.

11. It is more important for schools to promote academic achievement than social inclusion.

12. It is more important for schools to promote social inclusion than academic achievement.

13. I don't think I would have done as well academically if I had been in an inclusive classroom when at school.

14. I think I would have benefited from being part of the attention and special treatment of an inclusive classroom.

15. I enjoyed school and never had any real problem with learning.

16. The most important role of a school is to ensure academic excellence.

17. I think some people claim to have special educational needs to get extra attention and special treatment.

18. Emotional and behavioural problems are often just an excuse for lack of selfdiscipline.

19. It is a parent's role to ensure their child behaves properly. 
20. I think that parents are often to blame for their child's poor behaviour.

21. Pupils with emotional and behavioural problems should be excluded from mainstream classes as they disrupt other pupils' progress.

22. Education has a first duty to look after the interests of pupils who are trying to learn.

23. Parents should have the final say in which school their child attends.

24. I think it is impossible to try to accommodate too many differences in one classroom.

25. The best way to ensure equality of provision is for all pupils to be educated in an inclusive classroom.

26. Mainstream schools should not be allowed to exercise policies and structures that cater only for the needs of certain pupils, thereby excluding others with special educational needs.

27. Mainstream schools should have the final say in which pupils they can enrol. 